\title{
Is There Any Improvement of the Coagulation Imbalance in Sickle Cell Disease after Hematopoietic Stem Cell Transplantation?
}

\author{
Laurence Rozen ${ }^{1, *}$, Denis F. Noubouossie ${ }^{1}$, , Laurence Dedeken ${ }^{2}$, Phu Quoc Lê ${ }^{2}$, \\ Alina Ferster ${ }^{2}$ and Anne Demulder ${ }^{1}$ \\ 1 Laboratory of Hematology LHUB-ULB ULB Université Libre de Bruxelles, 1020 Brussels, Belgium; \\ noubouossie75@yahoo.fr (D.F.N.); Anne.DEMULDER@LHUB-ULB.BE (A.D.) \\ 2 Hematology Oncology Unit, Hôpital and niversitaire des Enfants Reine Fabiola, ULB Université Libre de \\ Bruxelles, 1020 Brussels, Belgium; laurence.dedeken@huderf.be (L.D.); phuquoc.le@huderf.be (P.Q.L.); \\ alina.ferster@huderf.be (A.F.) \\ * Correspondence: laurence.rozen@lhub-ulb.be; Tel.: +32-2477-2921
}

Received: 23 August 2019; Accepted: 23 October 2019; Published: 26 October 2019

\begin{abstract}
Several components of the clotting system are modified towards hypercoagulability in sickle cell disease (SCD). To date, hematopoietic stem cell transplantation (HSCT) is the only validated curative treatment of SCD. Here, we investigated the changes in the hemostatic potential of SCD children who've received a successful HSCT. Seventeen children with severe SCD were enrolled in the study. Thrombin generation (TG) was performed on citrated platelet-poor plasma, obtained before and 3, 6, 9, 12 and 15 months after HSCT. TG was triggered using $1 \mathrm{pM}$ tissue factor and $4 \mu \mathrm{M}$ phospholipids with or without thrombomodulin (TM). Before the HSCT, SCD children showed a higher endogenous thrombin potential (ETP), higher peak, higher velocity and shorter time-to-peak of TG than the normal controls (NC). ETP did not significantly change following the HSCT. However, the peak, velocity and time-to-peak of TG reversed to normal ranges from 3 months post-HSCT and remained so up to 15 months post-HSCT. The reduction of ETP after the addition of thrombomodulin (RETP) was dramatically reduced in SCD children before HSCT as compared with the NC. A partial reversal of RETP was observed from 3 months through 15 months post-HSCT. No statistical difference was observed for patient age or donor hemoglobinopathy status. In summary, successful HSCT improves the kinetics of TG but not the total thrombin capacity in SCD children.
\end{abstract}

Keywords: sickle cell disease; hematopoietic stem cell transplantation; thrombin generation test; coagulation; hemostatic potential

\section{Introduction}

Sickle cell disease (SCD) is considered as a hypercoagulable state. Clinical manifestations include venous thromboembolism and stroke in a subset of patients [1,2]. The activation of coagulation is often present, with consumptive coagulopathy as well as increased levels of in vivo markers of thrombin and fibrin generation $[3,4]$.

Several components of the clotting system are modified towards hypercoagulability in SCD. Previous studies have reported that patients with SCD present with alterations of several of the individual procoagulant and anticoagulant factors involved in the coagulation system (may it be pro or anticoagulants: elevated FVIII levels, decreased protein C, and protein S), but also an increase in the hemostatic potential using global tests of coagulation. Global tests reflect a better hemostatic balance than the usual test performed in a routine laboratory; they are the final result of the interaction between pro- or anti-coagulant factors. As thrombin is a central factor of the coagulation cascade, the evaluation 
of the thrombin generation (TG) is a key element in the evaluation of coagulation disorders and easy to measure thanks to the Calibrated Automated Method (CAT $\left.{ }^{\circledR}\right)$, developed by Hemker [5]. This method provides a curve characterized by an initiation phase (lag-time, corresponding to the clotting time of the routine tests) followed by an amplification phase reaching a peak of maximal thrombin formation. This phase is followed by a decay phase, corresponding to the intervention of anticoagulant factors. ETP (the area under the curve), represents the total amount of thrombin formed as a result of pro- and anticoagulant factors. Velocity represents the rate of thrombin formation, and time-to-peak the time to reach the peak of thrombin formation. Hypercoagulable states, as is the case in SCD, show a reduced lag-time, and increased ETP and peak [6]. Therefore, observations with global tests have demonstrated in children with SCD that, even at a steady state, hypercoagulability is present $[7,8]$. Elevated thrombin generation (TG) in SCD children has been described as being related to younger age as well as to the intensity of hemolysis and a link between TG and cerebral vasculopathy in these patients has been mentioned [9].

The treatment of SCD patients has been considerably improved with the introduction of hydroxyurea (HU) and with much better global medical management, at least in developed countries $[10,11]$. However, SCD remains associated with severe morbidity and decreased survival (organ failure, chronic damage). To date, matched sibling donor (MSD) hematopoietic stem cell transplantation (HSCT) is the only validated curative treatment of SCD [12].

HSCT is mainly considered for children with severe clinical disease characterized by a history of stroke, repeated vaso-occlusive crises (VOC), multiple acute chest syndrome (ACS), and multiple osteonecrosis or allo-immunization that hampers the appropriate management of acute or chronic complications [13]. Patients with deteriorating lung or kidney disease also benefit from transplantation [14] as well as children at risk of stroke [15].

The overall survival (OS) and event-free survival (EFS) after MSD-HSCT ranges from $93 \%$ to $97 \%$ and from $82 \%$ to $86 \%$ [16-20]. Despite these impressive clinical results, the evolution of the hemostatic balance following HSCT is still unknown.

According to a recent study [21], HSCT affects the coagulation system mainly in the first few weeks after transplantation. This study reports a clear shift towards a procoagulant state with an increase of the coagulation activation markers (Von Willebrand factor, pro-thrombin fragments $1+2$ ), fibrin turnover (D-dimers), and ETP. These early coagulation abnormalities can lead to an increased morbi-mortality rate [22], with transplant-associated thrombotic microangiopathy (TA-TMA) as a major side effect, mainly due to endothelial damage [23,24].

As SCD and HSCT confers a prothrombotic profile to patients, the aim of our study was to investigate whether the hemostatic imbalance in SCD children could improve following HSCT. We used the Calibrated Automated Thrombogram ${ }^{\circledR}$ to compare the hemostatic potential of SCD children before and after HSCT.

\section{Materials and Methods}

\subsection{Patients}

From November 2014 to March 2018, children with severe SCD undergoing MSD-HSCT were enrolled in the study. Before HSCT, all patients were suffering from severe clinical diseases, including cerebrovascular disease, recurrent ACS or frequent VOC $(\geq 2 /$ year).

\subsection{Controls}

The population of normal controls (NC) has already been described in a previous publication [25] and consisted of 23 children aged from 2 to 14 years who had a blood coagulation test before a minor elective surgery. The remaining plasmas of those samples were used as controls for the present study. 


\subsection{Blood Collection and Handling}

The study was approved by the local Ethics Committee of the Hôpital Universitaire des Enfants Reine Fabiola ( ${ }^{\circ}$ 25/09) and informed consent was obtained from each parent or legal tutor before transplant. The peripheral venous blood of patients and normal controls (NC) was collected into Vacutainer ${ }^{\circledR}$ tubes (BD, Plymouth, UK) containing buffered sodium citrate $(0.109 \mathrm{M})$. Venipuncture was performed using a butterfly $21 \mathrm{G}$ needle. Platelets-poor plasma was prepared within the hour after blood collection by a double centrifugation at $2500 \times \mathrm{g}$ for $15 \mathrm{~min}$. Samples were stored at $-80^{\circ} \mathrm{C}$ with an average time of between 6 and 12 months. Prior to analysis, samples were rapidly thawed for $5 \mathrm{~min}$ in a water bath at $37^{\circ} \mathrm{C}$.

\subsection{Thrombin Generation Assay}

TG was performed on citrated platelet-poor plasma, obtained before and 3, 6, 9, 12 and 15 months after HSCT using the CAT ${ }^{\circledR}$ method after the addition of $1 \mathrm{pM}$ tissue factor and $4 \mu \mathrm{M}$ phospholipids without and with thrombomodulin TM (PPP low +/- TM, Synapse BV). The detailed protocol has already been described by Noubouossie et al. [7,9].

Internal quality control was ensured by performing reference plasma (Poolnorm, Diagnostica Stago, Asnières, France) on each TG plate.

\subsection{Evaluation of Hemolysis and HbS}

These tests were performed in the samples collected for routine follow-up, in parallel with those collected for thrombin generation before HSCT, 6 and 15 months after HSCT. The rate of hemolysis was evaluated in SCD patients using total hemoglobin level (HB and plasma lactate deshydrogenase level LDH. The total hemoglobin level was measured in the blood collected in dipotassic EDTA tubes (Vacutainer ${ }^{\circledR}$, Becton Dickinson, Plymouth, UK) using an automate cell counter (Sysmex XN 9000 Sysmex Corporation TM, Kobe, Japan). The LDH levels were measured in the plasma collected in lithium heparin tubes with a gel separator (Vacutainer ${ }^{\circledR}$, Becton Dickinson, Plymouth, UK) using the LDHI2 on Cobas $8000^{\circledR}$ analyzer (Roche Diagnostics, Rotkreuz, Switzerland).

$\mathrm{HbS}$ was assessed by alkaline capillary electrophoresis (Capillarys systems, Sebia, Benelux).

\subsection{Statistical Analysis}

The TG parameters (endogenous thrombin potential (ETP), peak, velocity, time to peak, lag time) were measured. The reduction of ETP (RETP) in the presence of TM was calculated for each sample and expressed in percentage. Patient results were expressed as median with a range at each time point and compared with the range (percentile 2.5-97.5) of normal controls (NC).

The Mann-Whitney test was used to compare the NC and patients before HSCT and to compare TG for patients $<10$ years and $>10$ years and to compare TG after 15 months regarding AA versus AS donor.

The TG parameters were compared before and 3 months after HSCT using the Wilcoxon matched pairs test.

$\mathrm{Hb}, \mathrm{HbS}$ and LDH values were compared before HSCT and 6 and 15 months after HSCT with the Friedman test. In the cases where Friedman tests were significant, Dunn's post test was performed to compare all pairs of the groups.

The statistical calculations were realized using the software GraphPad Prism version 5 (Graph-Pad Software Inc., San Diego, USA). A P value less than 0.05 was considered significant. 


\section{Results}

\subsection{Demographic Data}

Seventeen children (five females, 12 males) were consecutively enrolled. Sixteen patients were homozygote $\mathrm{HbSS}$ and one was compound heterozygote $\mathrm{HbSB}+$. Three patients were on a chronic exchange transfusion program before HSCT, either for cerebro-vascular disease $(N=1)$ or recurrent ACS despite treatment with HU $(N=2)$. All the patients were treated with HU. The median age at transplantation was 9.6 years (range: 3.6-16.5 years). The stem cell donor was a matched sibling in all cases (11 were heterozygous AS, five were AA and one was heterozygous AC). The source of the stem cell was cord blood in one patient, bone marrow in 11 patients and bone marrow plus cord blood in five patients. Table 1 summarizes the demographic data.

All the patients received myeloablative conditioning regimen (Busulfan, Cyclophosphamide and Anti-thymocytes Globulins). The graft-versus-host disease (GVHD) prophylaxis included cyclosporine and methotrexate or cyclosporine and mycophenolate in the case of cord blood.

\subsection{Clinical Data}

All patients engrafted successfully. No acute GVHD occurred. One patient developed chronic extensive GVHD which was well controlled after steroids and extracorporeal photopheresis and could be stopped after five months. After a median follow-up of three years, all patients were alive with a full donor chimerism. Table 1 summarizes the clinical data.

\subsection{Thrombin Generation Parameters}

In the presence or absence of thrombomodulin, the ETP, peak and velocity of TG were significantly higher; lag time and time-to-peak were shorter, whereas the RETP was decreased in children with SCD before HSCT as compared with NC. As it represented a more complete situation, results with TM are illustrated in Figure 1. All values for the TG parameters are summarized in Table S1, in the Supplementary Materials.
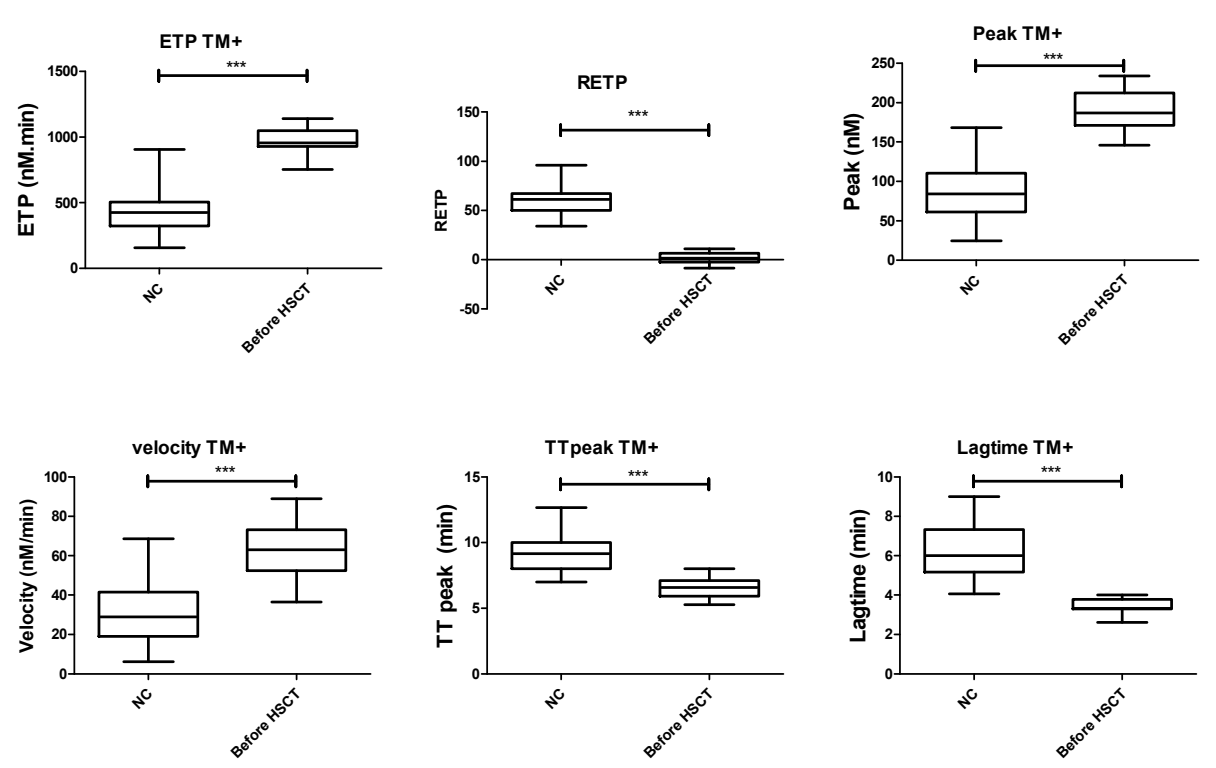

Figure 1. Comparison of the TG parameters with TM (median and range) between normal controls (NC) and sickle cell disease (SCD) patients before HSCT. ETP TM+: endogenous thrombin potential following addition of thrombomodulin, RETP: reduction of ETP with the addition of thrombomodulin, HSCT: hematopoietic stem cell transplantation, TM+: with addition of thrombomodulin, TT: time to peak, NC: normal control, ${ }^{* *} p<0.001$ as compared to the controls using the Mann-Whitney test. 
Table 1. Demographic data of the 17 patients, their donors, and clinical and biological data following hematopoietic stem cell transplantation (HSCT).

\begin{tabular}{|c|c|c|c|c|c|c|c|}
\hline \multicolumn{4}{|c|}{ Genotype patient } & \multicolumn{4}{|c|}{$16 \mathrm{HbSS}, 1 \mathrm{HbSB}+$} \\
\hline \multicolumn{4}{|c|}{ Sex } & \multicolumn{4}{|c|}{5 females, 12 males } \\
\hline \multicolumn{4}{|c|}{ Age at transplant (years) } & \multicolumn{4}{|c|}{$9.6(3.6-16.5)$} \\
\hline \multicolumn{4}{|c|}{ Donor Genotype } & \multicolumn{4}{|c|}{$11 \mathrm{HbAS}, 5 \mathrm{HbAA}, 1 \mathrm{HbAC}$} \\
\hline \multicolumn{4}{|c|}{ Donor sex } & \multicolumn{4}{|c|}{7 females, 10 males } \\
\hline \multirow{7}{*}{$\begin{array}{l}\text { HSCT } \\
\text { complications }\end{array}$} & \multicolumn{3}{|c|}{ Acute renal insuffisency } & \multirow{2}{*}{\multicolumn{4}{|c|}{$\begin{array}{l}\text { 1, resolved } 3 \text { months after transplant, due to drug toxicities) } \\
\text { 1, with mild hemorrhagic cystitis resolved less than1 month after transplant }\end{array}$}} \\
\hline & \multicolumn{3}{|c|}{ Hemorrhagic cystitis } & & & & \\
\hline & \multicolumn{3}{|c|}{ VOD } & \multicolumn{4}{|c|}{0} \\
\hline & \multirow{2}{*}{\multicolumn{3}{|c|}{$\begin{array}{l}\text { Acute GVHD } \\
\text { Chronic GVHD }\end{array}$}} & \multicolumn{4}{|c|}{0} \\
\hline & & & & \multicolumn{4}{|c|}{ 1, with no more immuno-suppressive treatment 12 months after transplant } \\
\hline & \multirow[b]{2}{*}{ Before HSCT } & \multirow[b]{2}{*}{$\begin{array}{l}6 \text { months after } \\
\text { HSCT }\end{array}$} & \multirow[b]{2}{*}{$\begin{array}{l}15 \text { months after } \\
\text { HSCT }\end{array}$} & \multirow[b]{2}{*}{ Friedmann test } & \multicolumn{3}{|c|}{ Dunn's post-test } \\
\hline & & & & & $\begin{array}{l}\text { Before versus } 6 \\
\text { months after } \\
\text { HSCT }\end{array}$ & $\begin{array}{c}\text { Before versus } 15 \\
\text { months after } \\
\text { HSCT }\end{array}$ & $\begin{array}{c}6 \text { months versus } \\
15 \text { months after } \\
\text { HSCT }\end{array}$ \\
\hline $\mathrm{Hb}(\mathrm{g} / \mathrm{dL})$ & $8.3(7.2-11.4)$ & $11.7(10.5-14.5)$ & $12.4(10.9-13.5)$ & $p<0.0001$ & ** & $* * *$ & NS \\
\hline $\mathrm{HbS}(\%)$ & $70(26-88)$ & $32(0-40)$ & $34(0-42)$ & $p=0.0001$ & $* * *$ & * & NS \\
\hline LDH & $466(256-823)$ & $243(185-488)$ & $235(177-317)$ & $p<0.0001$ & $* *$ & $* * *$ & NS \\
\hline
\end{tabular}

Data are expressed as median and range. VOD: vaso-occlusive disease, GVHD: graft-versus-host disease, Hb: hemoglobin, HbS: sickle hemoglobin, LDH: lactate deshydrogenase, HbSS: patient with sickle cell disease that are homozygote for $\mathrm{HbS}, \mathrm{HbSB}+$ : patient with sickle cell disease that are compound heterozygote for $\mathrm{HbS}$ and B+ tahalssémia, $\mathrm{Hb} \mathrm{AS}$ : sickle cell trait for $\mathrm{HbS}$, HbAC: sickle cell trait for HbC, HSCT: hematopoietic stem cell transplantation, NS: not significant $(p>0.05))^{*}: p<0.05, * * p<0.01$, **** $p<0.001$. 
At 3 months post-HSCT, peak and velocity significantly decreased while lag time and time-to-peak significantly increased as compared with pre-HSCT values, regardless of the presence or absence of TM. The median peak, velocity and time-to-peak returned to values within the normal range, set as (P2.5-P97.5) of the NC (see Figure 2 for results with TM). The lag time and RETP significantly increased at 3 months post-HSCT as compared with pre-HSCT. However, their median values did not return within the normal range, indicating a partial recovery (Table S1).

From three months through 15 months after HSCT, no further changes were observed in all TG parameters. Median ETP value remained higher while median RETP and median lag time values remained lower than P2.5-P97.5 of NC. In contrast, median values of the peak, time-to-peak and velocity of TG performed in the presence of TM stabilized within the P2.5-P97.5 of NC, suggesting a full recovery (Table 1 and Figure 2, for results with TM).

Otherwise, no statistical difference was observed for patient age or donor hemoglobinopathy status (data not shown but all $p$-value were $>0.05$ ).
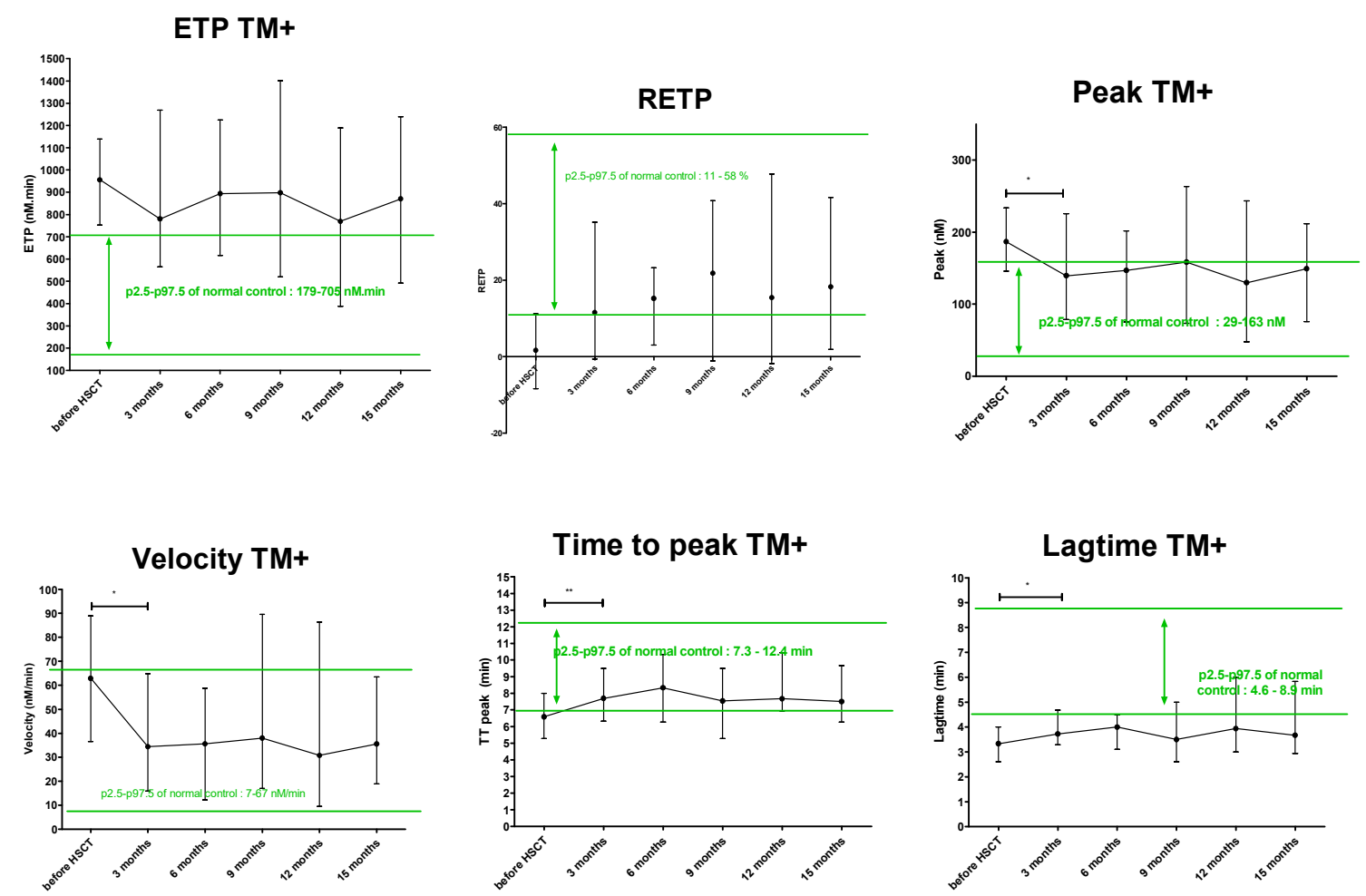

Figure 2. Modification of TG parameters (median and range) before and after successful HSCT, with $(\mathrm{TM}+)$ the addition of thrombomodulin. The range p2.5-p97.5 of NC is colored in green. ETP TM+: endogenous thrombin potential following addition of thrombomodulin, RETP: reduction of ETP with the addition of thrombomodulin, HSCT: hematopoietic stem cell transplantation, TM+: with addition of thrombomodulin, NC: normal control, ${ }^{*}: p<0.05,{ }^{* *} p<0.01$.

\subsection{Evolution Ofhemoglobin, $H b S$ and $L D H$}

Median hemoglobin, $\mathrm{HbS}$ and LDH are summarized in Table 1. They change significantly after HSCT. When compared to pre HSCT values, at 6 months, total hemoglobin increased from $8.3 \mathrm{~g} / \mathrm{dL}$ (range: $7.2-11.4)$ to $11.7 \mathrm{~g} / \mathrm{dL}$ (range: $10.5-14.5)(p<0.01) . \mathrm{HbS}$ and LDH decreased from $70 \%$ (range: $26-88)$ to $32 \%$ (range: $0-40)(p<0.001$ ) and from $466 \mathrm{UI} / \mathrm{L}$ (range: $256-823)$ to $243 \mathrm{UI} / \mathrm{L}$ (range: 185-488) $(p<0.01)$, respectively. The comparison of 15 months before and after HSCT showed similar results while the comparison between 6 and 15 months after HSCT did not show any significant changes.

These observations were similar even when not taking into account the three patients under exchange transfusion before HSCT. 


\section{Discussion}

To our knowledge, this is the first study addressing the changes in the clotting system following HSCT. As expected, SCD patients in this study presented a hypercoagulable state as compared to the NC before HSCT. This hypercoagulable state included a faster time to generate thrombin (lag time and time-to-peak are shorter in SCD than in NC), a faster rate of thrombin production (velocity is higher in SCD than in NC), a higher concentration and total capacity to generate thrombin (peak and ETP are higher in SCD than in NC). The altered global coagulation in patients with SCD before HSCT was previously highlighted by our team in a limited cohort [26] and by Gerotziafas et al. [8]. Several synergistic factors have been suggested to explain the increased hemostatic potential in patients with SCD. Indeed, we and others have previously reported the decreased levels of protein $C$ and protein $S$ in these patients [26-31]. Protein C and protein S are known determinants of TG [32] and decreased levels of these proteins induce a resistance to thrombomodulin [33]. In addition, elevated FVIII levels in these patients inversely correlate with RETP and may contribute to some resistance to activated protein C [34].

Circulating levels of pro-coagulant microvesicles deriving from blood and endothelial cells have also been reported in patients with SCD [35-38]. Some of these microvesicles, especially those released by activated monocytes or endothelial cells, expose functional tissue factor that may contribute to shortening the lag time and the time-to-peak of TG in these patients [36]. Procoagulant microvesicles also expose phosphatidylserine, a procoagulant phospholipid that provides the surface for the assembly of coagulation complexes. We have previously shown that increased microvesicle-bearing phospholipid procoagulant activity in the plasma of patients with SCD contributes to accelerated velocity and an elevated peak of TG [39].

These results were observed both with and without thrombomodulin. This protein sensitizes TG to the protein C/protein S anticoagulant pathway and allows a more global exploration of the coagulation balance. Therefore, we observed an extremely low RETP before HSCT which emphasizes the prothrombotic profile resulting from the impairment of the protein $C$ and protein $S$ anticoagulant pathway.

Furthermore, the altered hemostatic balance before HSCT seems to be linked to a hemolysisendothelial dysfunction phenotype, as suggested by the significant correlations previously reported between markers of hemolysis and parameters of TG in children with SCD [39]. This can be supported by the low $\mathrm{Hb}$ and the high LDH level before HSCT.

Our results indicate a clear trend toward the resolution of the hypercoagulable state in SCD as soon as 3 months following successful allogeneic HSCT, as evidenced by the reversal of the kinetic parameters of TG to normal values. This is likely the result of the replacement of sickle red cells by engrafted non-sickle erythrocytes, leading to a decreased level of circulating erythrocyte-derived phosphatidylserine-positive microvesicles. As stated earlier, the level of these microvesicles have been shown to be a critical determinant of the propagation phase of TG in patients with SCD [39]. Interestingly, the improvement of the kinetics of TG persisted over time and was sustainable up to 15 months after engraftment. In parallel, $\mathrm{Hb}$ increased, while $\mathrm{HbS}$ and $\mathrm{LDH}$ level decreased after HSCT and tended towards normal values.

Some TG parameters-lag time, ETP and RETP for instance-did not return to normal values. RETP improved after HSCT suggesting a partial recovery of the impaired protein C/protein S anticoagulant pathway [40]. The reasons for these findings are unclear. Since the study was performed in a pediatric population, we could not get enough sample volume to measure other coagulation parameters, including individual coagulation factors, physiologic anticoagulants, D-dimers and microvesicles. These will be addressed in further studies with the aim to better understand the underlying mechanisms of our observations. Nonetheless, a persistent inflammatory state following HSCT may lead to circulating tissue factor and an elevated level of FVIII, which are potential factors that can contribute to the maintenance of a short lag time, high ETP and reduced RETP in these patients.

Our study has some other limitations. The first one is that it was only centered on SCD children. Indeed, HSCT in SCD is mainly performed during childhood. Our observations might be extendable 
to SCD adults as they have a similar procoagulant profile. However, the impact of HSCT on the hemostatic system of adults could be different. The second limitation is that the population of the NC was not entirely race matched as it also included Caucasian children. It is well recognized that African people have a higher incidence of thromboembolism as compared to "white" people [41,42]. Roberts et al. reported that African-Caribbean adults have a higher TG profile than Caucasians, with higher peak, ETP and velocity [43]. Despite the fact that lag time, time-to-peak and ETP reduction were not significantly different in Roberts's study, this highlights the fact that TG studies are influenced by ethnicity. In further studies, we intend to use sibling donors as potential controls. Nevertheless, it is a significant challenge to get samples from normal controls in children for coagulation studies.

Finally, our study is monocentric and concerns a small cohort of patients who all had a successful MSD-HSCT after myeloablative conditioning with full donor chimerism. Our results may not be extrapolated to patients who develop mixed chimerism after transplantation.

\section{Conclusions}

To summarize, a successful HSCT reverses accelerated coagulation reactions in children with SCD. No thromboembolic events were recorded in the patients studied. However, further properly designed studies are essential to evaluate the clinical impact and the underlying mechanisms of the changes induced by HSCT on coagulation in SCD.

Supplementary Materials: The following are available online at http://www.mdpi.com/2077-0383/8/11/1796/s1, Table S1: Thrombin generation parameters for NC and for SCD children before and after successful allogeneic hematopoietic stem cell transplantation.

Author Contributions: D.F.N., A.F. and A.D. designed the study; L.R. performed the experiments, L.D., P.Q.L. and A.F. enrolled the patients, L.R. and L.D. performed the statistical analyses, L.R. wrote the manuscript., D.F.N., L.D., A.D., A.F., P.Q.L. reviewed and edited the manuscript.

Funding: No funding was received for this study.

Acknowledgments: This work was partially supported by grants from Shire, Bayer and CSL Behring. The authors would like to thank all the patients and their parents, nurses and physicians of the hemato-oncology unit at HUDERF for their contribution to sample collection, technicians of our laboratory for their contribution to samples handling.

Conflicts of Interest: The authors declare no conflict of interest.

\section{References}

1. De Franceschi, L.; Cappellini, M.D.; Olivieri, O. Thrombosis and sickle cell disease. Semin. Thromb. Hemost. 2011, 37, 226-236. [CrossRef] [PubMed]

2. Austin, H.; Key, N.S.; Benson, J.M.; Lally, C.; Dowling, N.F.; Whitsett, C.; Hooper, W.C. Sickle cell trait and the risk of venous thromboembolism among blacks. Blood 2007, 1, 908-912. [CrossRef] [PubMed]

3. Ataga, K.I.; Key, N.S. Hypercoagulability in sickle cell disease: New approaches to an old problem. Hematol. Am. Soc. Hematol. Educ. Program. 2007, 91-96. [CrossRef]

4. Noubouossie, D.; Key, N.S.; Ataga, K.I. Coagulation abnormalities of sickle cell disease: Relationship with clinical outcomes and the effect of disease modifying therapies. Blood Rev. 2016, 30, 245-256. [CrossRef] [PubMed]

5. Hemker, H.C.; Giesen, P.; Al Dieri, R.; Regnault, V.; de Smedt, E.; Wagenvoord, R.; Lecompte, T.; Béguin, S. Calibrated automated thrombin generation measurement in clotting plasma. Pathophysiol. Haemost. Thromb. 2003, 33, 4-15. [CrossRef] [PubMed]

6. Duarte, R.C.F.; Ferreira, C.N.; Rios, D.R.A.; Reis, H.J.D.; Carvalho, M.D.G. Thrombin generation assays for global evaluation of the hemostatic system: Perspectives and limitations. Rev. Bras. Hematol. Hemoter. 2017, 39, 259-265. [CrossRef]

7. Noubouossie, D.F.; Lê, P.Q.; Corazza, F.; Debaugnies, F.; Rozen, L.; Ferster, A.; Demulder, A. Thrombin generation reveals high procoagulant potential in the plasma of sickle cell disease children. Am. J. Hematol. 2012, 87, 145-149. [CrossRef] 
8. Gerotziafas, G.T.; Van Dreden, P.; Chaari, M.; Galea, V.; Khaterchi, A.; Lionnet, F.; Stankovic-Stojanovic, K.; Blanc-Brude, O.; Woodhams, B.; Maier-Redelsperger, M.; et al. The acceleration of the propagation phase of thrombin generation in patients with steady-state sickle cell disease is associated with circulating erythrocyte-derived microparticles. Thromb. Haemost. 2012, 107, 1044-1052. [CrossRef]

9. Noubouossie, D.C.; Lê, P.Q.; Rozen, L.; Ziereisen, F.; Willems, D.; Demulder, A.; Ferster, A. Thrombin generation in children with sickle cell disease: Relationship with age, hemolysis, transcranial Doppler velocity, and hydroxyurea treatment. Eur. J. Haematol. 2013, 91, 46-54. [CrossRef]

10. Quinn, C.T.; Rogers, Z.R.; McCavit, T.L.; Buchanan, G.R. Improved Survival of Children and Adolescents with Sickle Cell Disease. Blood 2010, 115, 3447-3452. [CrossRef]

11. Hamideh, D.; Alvarez, O. Sickle Cell Disease Related Mortality in the United States (1999-2009). Pediatric Blood Cancer 2013, 60, 1482-1486. [CrossRef] [PubMed]

12. Talano, J.A.; Cairo, M.S. Hematopoietic stem cell transplantation for sickle cell disease: State of the science. Eur. J. Haematol. 2015, 94, 391-399. [CrossRef] [PubMed]

13. Locatelli, F.; Pagliara, D. Allogeneic hematopoietic stem cell transplantation in children with sickle cell disease. Pediatric Blood Cancer 2012, 59, 372-376. [CrossRef] [PubMed]

14. Powars, D.; Weidman, J.A.; Odom-Maryon, T.; Niland, J.C.; Johnson, C. Sickle cell chronic lung disease: Prior morbidity and the risk of pulmonary failure. Medicine 1988, 67, 66-76. [CrossRef] [PubMed]

15. Bernaudin, F.; Verlhac, S.; Peffault de Latour, R.; Dalle, J.H.; Brousse, V.; Petras, E.; Thuret, I.; Paillard, C.; Neven, B.; Galambrun, C.; et al. Association of Matched Sibling Donor Hematopoietic Stem Cell Transplantation with Transcranial Doppler Velocities in Children with Sickle Cell Anemia. JAMA 2019, 321, 266-276. [CrossRef]

16. Bhatia, M.; Walters, M.C. Hematopoietic Cell Transplantation for Thalassemia and Sickle Cell Disease: Past, Present and Future. Bone Marrow Transpl. 2008, 41, 109-117. [CrossRef]

17. Bernaudin, F.; Socie, G.; Kuentz, M.; Chevret, S.; Duval, M.; Bertrand, Y.; Vannier, J.P.; Yakouben, K.; Thuret, I.; Bordigoni, P.; et al. Long-term Results of Related Myeloablative Stem-cell Transplantation to Cure Sickle Cell Disease. Blood 2007, 110, 2749-2756. [CrossRef]

18. Dedeken, L.; Lê, P.Q.; Azzi, N.; Brachet, C.; Heijmans, C.; Huybrechts, S.; Devalck, C.; Rozen, L.; Ngalula, M.; Ferster, A. Haematopoietic stem cell transplantation for severe sickle cell disease in childhood: A single centre experience of 50 patients. Br. J. Haematol. 2014, 165, 402-408. [CrossRef]

19. Gluckman, E.; Cappelli, B.; Bernaudins, F.; Labopins, M.; Volts, F.; Carreras, J.; Pinto Simões, B.; Ferster, A.; Dupont, S.; de la Fuente, J.; et al. Eurocord, the Pediatric Working Party of the European Society for Blood and Marrow Transplantation, and the Center for International Blood and Marrow Transplant Research. Sickle cell disease: An international survey of results of HLA-identical sibling hematopoietic stem cell transplantation. Blood 2017, 129, 1548-1556. [CrossRef]

20. Cappelli, B.; Volt, F.; Tozatto-Maio, K.; Scigliuolo, G.M.; Ferster, A.; Dupont, S.; Pinto Simões, B.; Al-Seraihy, A.; Aljurf, M.D.; Almohareb, F.; et al. Risk factors and outcomes according to age at transplantation with an HLA-identical sibling for sickle cell disease. Haematologica 2019, 104. [CrossRef]

21. Långström, S.; Koskenvuo, M.; Huttunen, P.; Lassila, R.; Taskinen, M.; Ranta, S.; Heikinheimo, M.; Mäkipernaa, A. Haematopoietic Stem Cell Transplantation in Children Shifts the Coagulation System towards a Pro-Coagulant State. Thromb. Haemost. 2018, 118, 1390-1396. [CrossRef] [PubMed]

22. Nagasawa, M.; Ohkawa, T.; Endo, A.; Mitsuiki, N.; Ono, T.; Aoki, Y.; Isoda, T.; Tomizawa, D.; Takagi, M.; Kajiwara, M.; et al. Early coagulation disorder after allogeneic stem cell transplantation is a strong prognostic factor for transplantation-related mortality, and intervention with recombinant human thrombomodulin improves the outcome: A single-center experience. Int. J. Hematol. 2013, 98, 533-542. [CrossRef] [PubMed]

23. Dvorak, C.C.; Higham, C.; Shimano, K.A. Transplant-Associated Thrombotic Microangiopathy in Pediatric Hematopoietic Cell Transplant Recipients: A Practical Approach to Diagnosis and Management. Front. Pediatric 2019, 7, 133. [CrossRef] [PubMed]

24. Rosenthal, J. Hematopoietic cell transplantation-associated thrombotic microangiopathy: A review of pathophysiology, diagnosis, and treatment. J. Blood Med. 2016, 7, 181-186. [CrossRef] [PubMed]

25. Rozen, L.; Noubouossie, D.; Dedeken, L.; Huybrechts, S.; Le, P.Q.; Ferster, A.; Demulder, A. Different profile of thrombin generation in children with acute lymphoblastic leukaemia treated with native or pegylated asparaginase-A cohort study. Pediatric Blood Cancer 2017, 64, 294-301. [CrossRef] 
26. Noubouossie, D.F.; Emmerechts, J.; Debaugnies, F.; Le, P.Q.; Rozen, L.; Hoylaerts, M.F.; Demulder, A.; Ferster, A. Towards an Improvement of the Coagulation Imbalance in Sickle Cell Disease After Hematopoietic Stem Cell Transplantation: A Preliminary Study. Blood 2011, 118, 4840. [CrossRef]

27. Yee, D.L.; Edwards, R.M.; Mueller, B.U.; Teruya, J. Thromboelastographic and hemostatic characteristics in pediatric patients with sickle cell disease. Arch. Pathol. Lab. Med. 2005, 129, 760-765. [CrossRef]

28. Bezeaud, A.; Venisse, L.; Helley, D.; Trichet, C.; Girot, R.; Guillin, M.-C. Red blood cells from patients with homozygous sickle cell disease provide a catalytic surface for factor Va inactivation by activated protein C. Br. J. Haematol. 2002, 117, 409-413. [CrossRef]

29. Bayazit, A.K.; Kilinç, Y. Natural coagulation inhibitors (protein C, protein S, antithrombin) in patients with sickle cell anemia in a steady state. Pediatric Int. 2001, 43, 592-596. [CrossRef]

30. Wright, J.G.; Malia, R.; Cooper, P.; Thomas, P.; Preston, F.E.; Serjeant, G.R. Protein C and protein S in homozygous sickle cell disease: Does hepatic dysfunction contribute to low levels? Br. J. Haematol. 1997, 98, 627-631. [CrossRef]

31. Westerman, M.P.; Green, D.; Gilman-Sachs, A.; Beaman, K.; Freels, S.; Boggio, L.; Allen, S.; Zuckerman, L.; Schlegel, R.; Williamson, P. Antiphospholipid antibodies, proteins $\mathrm{C}$ and $\mathrm{S}$, and coagulation changes in sickle cell disease. J. Lab. Clin. Med. 1999, 134, 352-362. [CrossRef]

32. Dielis, A.W.J.H.; Castoldi, E.; Spronk, H.M.H.; van Oerle, R.; Hamulyák, K.; Ten Cate, H.; Rosing, J. Coagulation factors and the protein $\mathrm{C}$ system as determinants of thrombin generation in a normal population. J. Thromb. Haemost. 2008, 6, 125-131. [CrossRef] [PubMed]

33. Whelihan, M.F.; Lim, M.Y.; Mooberry, M.J.; Piegore, M.G.; Ilich, A.; Wogu, A.; Cai, J.; Monroe, D.M.; Ataga, K.I.; Mann, K.G.; et al. Thrombin generation and cell-dependent hypercoagulability in sickle cell disease. J. Thromb. Haemost. 2016, 14, 1941-1952. [CrossRef] [PubMed]

34. Noubouossie, D.; Lê, P.Q.; Rozen, L.; Willems, D.; Mujinga, N.M.; Ferster, A.; Demulder, A. Factor VIII level correlates with hemolysis and may contribute to the hypercoagulability of children with sickle cell disease. PB 2.55-1. J. Thromb. Haemost. 2013, 11, 710-711.

35. Van Beers, E.J.; Schaap, M.C.L.; Berckmans, R.J.; Nieuwland, R.; Sturk, A.; van Doormaal, F.F.; Meijers, J.C.; Biemond, B.J.; CURAMA study group. Circulating erythrocyte-derived microparticles are associated with coagulation activation in sickle cell disease. Haematologica 2009, 94, 1513-1519. [CrossRef]

36. Van Tits, L.J.; van Heerde, W.L.; Landburg, P.P.; Boderie, M.J.; Muskiet, F.A.J.; Jacobs, N.; Duits, A.J.; Duits, A.J.; Schnog, J.B. Plasma annexin A5 and microparticle phosphatidylserine levels are elevated in sickle cell disease and increase further during painful crisis. Biochem. Biophys. Res. Commun. 2009, 390, 161-164. [CrossRef]

37. Shet, A.S.; Aras, O.; Gupta, K.; Hass, M.J.; Rausch, D.J.; Saba, N.; Koopmeiners, L.; Key, N.S.; Hebbel, R.P. Sickle blood contains tissue factor-positive microparticles derived from endothelial cells and monocytes. Blood 2003, 102, 2678-2683. [CrossRef]

38. Westerman, M.; Pizzey, A.; Hirschman, J.; Cerino, M.; Weil-Weiner, Y.; Ramotar, P.; Eze, A.; Lawrie, A.; Purdy, G.; Mackie, I.; et al. Microvesicles in haemoglobinopathies offer insights into mechanisms of hypercoagulability, haemolysis and the effects of therapy. Br. J. Haematol. 2008, 142, 126-135. [CrossRef]

39. Noubouossie, D.C.; Lê, P.Q.; Rozen, L.; Debaugnies, F.; Ferster, A.; Demulder, A. Evaluation of the procoagulant activity of endogenous phospholipids in the platelet-free plasma of children with sickle cell disease using functional assays. Thromb. Res. 2012, 130, 259-264. [CrossRef]

40. Tripodi, A. Modified endogenous thrombin potential with results expressed as ratio of values with-to-without thrombomodulin. Thromb. Haemost. 2017, 117, 830-836. [CrossRef]

41. White, R.H.; Zhou, H.; Gage, B.F. Effect of age on the incidence of venous thromboembolism following major surgery. J. Thromb. Haemost. 2004, 2, 1327-1333. [CrossRef] [PubMed]

42. White, R.H.; Zhou, H.; Murin, S.; Harvey, D. Effect of ethnicity and gender on the incidence of venous thromboembolism in a diverse population in California. Thromb. Haemost. 2005, 93, 298-305. [PubMed]

43. Roberts, L.N.; Patel, R.K.; Chitongo, P.; Bonner, L.; Arya, R. African-Caribbean ethnicity is associated with a hypercoagulable state as measured by thrombin generation. Blood Coagul. Fibrinolysis 2013, 24, 40-49. [CrossRef] [PubMed]

(C) 2019 by the authors. Licensee MDPI, Basel, Switzerland. This article is an open access article distributed under the terms and conditions of the Creative Commons Attribution (CC BY) license (http://creativecommons.org/licenses/by/4.0/). 